\title{
Chapter 9 \\ The Crisis: Its Management and Impact on Equity and Democracy in Portugal and Possible Consequences for the $\mathrm{EU}$
}

\author{
Kai Enno Lehmann
}

\begin{abstract}
This chapter analyses the reaction of Portugal to the Euro crisis, in particular, the absence of popular revolt, and explores the possibilities to replicate the 'Portuguese experience' elsewhere.
\end{abstract}

\section{Introduction}

To say the global economic crisis from 2008 onwards hit Portugal hard would be both a statement of the obvious, as well as an understatement. The country went through a deep recession, painful 'structural reforms' and suffered high unemployment and a 'brain drain' of mostly young people. In this sense, Portugal has been no different to the experiences of Spain, Greece or Italy from within the European Union (EU). Yet, unlike those three other countries, Portugal has not suffered a 'populist revolt' from the political Right or Left. Instead, Portugal today is often seen as an example of a successful economic recovery without suffering social or political rupture.

The present chapter asks not only whether such a statement is accurate but what explains this apparent absence of a popular revolt. Looking at social, political and economic indicators, it will trace the evolution of Portugal over the last 10 years since the onset of the financial crisis. The central argument put forward here will be that, whilst it is useful to look at the Portugal case in the context of the global economic crisis to see what 'lessons can be learned', we should be careful in drawing too many conclusions for other cases and replicating the 'Portugal experience' elsewhere since much of what has happened in the country needs to be put into the context of its particularities. Therefore, any attempt to replicate its approach elsewhere will most likely fail. Any lessons need to be 're-adapted' to the particular circumstances of other countries.

\footnotetext{
K. E. Lehmann $(\varangle)$

University of São Paulo, São Paulo, Brazil

e-mail:klehmann@usp.br
} 


\section{The Context: Portugal Before the Crash-Not All Well, Even Then}

There is a lot of literature today looking at the origins of the economic crisis of 2008 or the origins of the Eurozone crisis (Giddens 2015; Krugman 2012; Lane 2012; amongst many). Whilst this literature is hugely informative, it frequently overlooks national particularities. In the case of Portugal, one of the key factors in this respect is the fact that, by 2008, the country had essentially been in economic crisis mode for many years.

As Reis (2013) argued, the country had been in economic difficulties since at least the year 2000, suffering a serious economic contraction between 1999 and 2000. ${ }^{1}$ This was accompanied by rising unemployment and years of anaemic productivity (ibid: 144). The then Chief Economist of the International Monetary Fund, Olivier Blanchard, warned in 2007 that 'Portugal is in serious trouble [...] Growth is very low. The budget deficit is large. The current account deficit is very large ... In the absence of policy changes, the most likely scenario is one of competitive disinflation, a period of sustained high unemployment until competitiveness has been reestablished' (Portugal 2015: 6).

Subsequent history confirmed these warnings. Apart from a crisis of growth, the country was also dealing with a chronic budget deficit which, in 2005, already stood at $6.2 \%$ of GDP, ${ }^{2}$ way above the $3 \%$ stipulated by the rules of the Eurozone. In fact, according to Pereira and Wemans (2012), from the year of its re-democratization to the onset of the economic crisis, there had never been a surplus in the state budget. As such, it should come as no surprise that the Portuguese state accumulated high levels of debt over the decades. In fact, Portugal's fiscal position since democratization had been so perilous that, since 1976, the International Monetary Fund instigated 'fiscal consolidation programs' for the country on three different occasions (Lourtie 2011). When, therefore, in 2009, the debt-to-GDP ratio was at $83.6 \%$ (a ratio which worsened steadily in subsequent years), it was, whilst alarming, not actually anything new. ${ }^{3}$ Rather, it followed a historical pattern which the country had gone through several times. Just as importantly, household debt in the country had also risen steadily prior to 2008 . Whereas in 1995 , it was $35.1 \%$ of GDP, by 2008, it had already reached more than $90 \% .^{4}$ These figures hint at deep structural problems within the Portuguese economy which both pre-date, at least partially caused, and overlay the crisis from 2008. In order, therefore, to understand the extent and impact of the 2008 crisis, it is worth having a look at these issues.

\footnotetext{
${ }^{1}$ See https://data.worldbank.org/country/Portugal. Accessed 15 May 2019.

${ }^{2}$ See https://countryeconomy.com/deficit/portugal. Accessed 15 May 2019.

${ }^{3}$ Data from https://tradingeconomics.com/portugal/government-debt-to-gdp. Accessed 15 May 2019.

${ }^{4}$ https://www.ceicdata.com/en/indicator/portugal/household-debt\%2D\%2Dof-nominal-gdp Accessed15 May 2019.
} 
One such structural issue is the size of informal economy. According to some estimates, the informal sector in Portugal accounted for approx. 23\% of GDP, significantly above the share of most — though by no means all-EU member states prior to 2004 (Barbosa et al. 2013). To give just one example, in Austria, a comparable country in terms of size, just under $10 \%$ of the economy was classed as informal in 2007 (ibid). This informality, in turn, has an impact on the tax base from which the Portuguese state can finance its activities. In 2008, on the eve of the crisis, the tax-to-GDP ratio was a touch over $21 \% .^{5}$

A second structural issue has been a long-standing problem with the quality of jobs created. According to the European Union itself, '[ $t$ ] he prevalence of low qualified workers in the Portuguese labour market has been considered as one of the most important constrains to national competitiveness and development' ${ }^{6}$ Such jobs tend to be less secure and low-paid, making those holding them far more susceptible to economic shocks. An economy based on such type of employment simply lacks the resilience to be able to cope with economic shocks over which the country in question itself may have very little influence. This lack of resilience is underpinned by an education system which does not adequately prepare Portugal's young population for the changing working environment (OECD 2015; Pereira and Wemans 2012). Uneven educational attainment contributed to an entrenchment of a lack of social mobility and high levels of social inequality.

The critical point is to realize that, when the economic crisis hit the Eurozone in 2008, Portugal was both already in economic difficulties as a result of a myriad of factors as well as ill-prepared to withstand any further shocks. In simple terms, the economy was not resilient enough to be able to cope with, or adapt to, the crisis which unfolded from 2008 onwards. As a consequence, Portugal was one of the countries hardest hit. This was most obviously shown in the country's unemployment rate, which rose from a little under $8 \%$ in 2008 to just under $18 \%$ by 2013 , underpinning in the process two of the structural problems touched upon above: the persistence of a large, informal economy as well as a brain drain from the country of primarily young people (Khalip 2015). ${ }^{7}$

This being the case, there was general gloom around Portugal's prospects of escaping this vicious economic cycle it seemed to be trapped in. This gloom was added to by problems within the political system which, once again, were long-standing. At national level, Portuguese politics since re-democratization has been marked by extended periods of - more or less stable — coalition and/or minority governments (Lloyd-Jones 2001; Lobo 2001). Particularly on the left of the political spectrum, the country has been marked by political fragmentation and instability (Bale 2008). This situation did not lend itself to long-term planning and strategic thinking to make the country more resilient and address the structural factors touched upon above.

\footnotetext{
${ }^{5}$ https://data.worldbank.org/indicator/GC.TAX.TOTL.GD.ZS?locations=PT. Accessed 15 May 2019.

${ }^{6}$ https://www.eurofound.europa.eu/publications/report/2009/portugal-quality-of-work-andemployment-of-low-qualified-workers. Accessed 15 May 2019.

${ }^{7}$ See https://tradingeconomics.com/portugal/unemployment-rate. Accessed 15 May 2019.
} 
The impact of the economic crisis, then, has to be seen within this context: a country with a relatively young, and fragile, democracy which had proved itself to be incapable of developing and implementing policies capable of tackling the deep structural economic problems the county faced. It is here that we need to look at the role of the European Union within this scenario.

\section{The Response and Role of the European Union}

The above argument has some critical implications for the role of the European Union in the crisis and prior to it. Historically, Portugal's membership of the EU has been seen as enormously beneficial to the country in general and its economy in particular. For instance, from the year before its accession in 1986 to the eve of the economic crisis in 2008, GDP per head in the country rose from $\$ 2705$ to $24,816 .{ }^{8}$ Equally, for most of its life as an EU member, Portugal saw an inflow of foreign direct investment. ${ }^{9}$ As a result, public opinion surveys have consistently shown large support in Portugal for EU membership over the years, as well as for membership of the single currency, of which Portugal is a founding member. ${ }^{10}$

This public support, as well as the severity and long-standing nature of the crisis as described above, gave the EU some political cover and freedom to act, particularly bearing in mind that Portugal has had experience of receiving outside 'assistance' or 'interference' (depending on one's point of view) in macroeconomic management in response to economic crises or challenges, as was the case in preparation of entry to the single currency during the 1990s (Bale 2008; Lloyd-Jones 2001). The response of the EU to the crisis was what one 'traditional'. In agreeing a so-called 'bailout' programme to stop the country falling into bankruptcy, the EU-together with the European Central Bank and the International Monetary Fund, the 'Troika' - required Portugal to undertake some significant macroeconomic adjustments. In return for a three-year loan worth approximately $78 \mathrm{bn}$ euros, the country undertook to implement:

- A public sector wage freeze and limiting promotion opportunities

- An increase in sales tax (VAT) on some items, such as cars

- The privatization of parts of the national energy company as well as the whole of the national airline TAP

- The reduction of some pensions and the freezing of others and

- A further limiting of the amount of time unemployment benefit can be paid.

\footnotetext{
${ }^{8}$ See https://www.macrotrends.net/countries/PRT/portugal/gdp-per-capita. Accessed 15 May 2019.

${ }^{9}$ See https://data.worldbank.org/indicator/BM.KLT.DINV.WD.GD.ZS?locations=PT.Accessed 15 May 2019.

${ }^{10}$ For the historical series, see https://ec.europa.eu/commfrontoffice/publicopinion/index.cfm/ Chart/index. Accessed 15 May 2019.
} 
In putting forward these measures, the key objectives were to 'maintain the stability of the Portuguese financial sector and to buffer the domestic impact of the crisis' (Portugal 2015: 10). Unsurprisingly, as elsewhere in Europe, the measures put forward by the Troika were heavily contested. From an economic point of view, many have argued that the austerity measures contained in the bailout plan would have a detrimental impact both on the economy as a whole and people's living standards individually (Pedroso 2014). Politically, there was strong criticism from many quarters about the fact that the European Union, at least initially, did nothing to address the flaws in the design of the single currency and associated fiscal processes despite the fact that, after Ireland and Greece, Portugal was the third Eurozone country needed to be bailed out in order to avoid sliding into bankruptcy (Costa et al. 2016). This suggests that there are evident, and profound, structural problems in the design of the EU's monetary union, and these are those which need to be addressed in order to avoid future crises.

This ties into broader arguments made about the policy focus of the European Union. As outlined above, Portugal has suffered from long-standing structural problems in its economy which were somewhat masked by the macroeconomic performance of the country since it joined the EU in 1986. As a result, the failure to address these structural problems was often overlooked, including by the EU. As Bittner (2010) has argued, the unwillingness and/or inability of the EU to address structural problems has been one of the most striking defects of its work over a long period of time, and the crisis which came about in Portugal (as well as elsewhere) was only one of the many manifestations of this failure (see also Lehmann 2018).

In the specific case of Portugal linked to this was also the worry of the country following in the footsteps of Greece, Spain and Italy_amongst others - which have had to content with the rise of populist parties from both the right and left in response to the economic crises the respective countries passed through after 2008 (Giddens 2015). Yet, in Portugal, the surge of populist parties has not occurred. There has been an intense debate in the academic literature as to what, in contrast to several other European countries, explains this absence of populism in Portuguese politics and society at large. In this literature, one can detect several explanations, roughly grouped under demography, history, culture and specific local contemporary factors. It is worth looking at these briefly in turn.

\section{The Absence of Populism in Portugal?}

The first factor explaining the absence of a strong, anti-establishment party in Portugal is the make-up of its political, and party, system. Critically in this respect, Portugal actually has a long history of having relatively strong 'outlier' parties. Ever since democratization from the mid-1970s onwards, the Portuguese Communist Party, for instance, has consistently polled in the region of $10 \%$ of the vote, be it in local or national elections (Llana 2015). That means that there is little room, on the Left at least, for a 'protest party'. It already exists but is part of the political mainstream. 
Linked to this is Portuguese history. Unlike Greece or Spain, the country does not have a contentious recent history. It has not had the experience of a civil war, like Greece, or strong regional separatist movements which, in some cases, have included a long-lasting terrorist campaign, as in the case of Spain. Portugal's history is, in this sense, more consensual, lacking both the precedents and incentives to pursue radical policies and radical politics aimed at overthrowing 'the system'. The experience of relatively consensual coalition governments since 1974 plays into this context. Portugal is not a country to which 'revolution' comes easily (Morlino and Raniolo 2017; Lloyd-Jones 2001).

The second key factor when discussing the absence of explicitly populist parties is the way politics is done in Portugal (Magalhães 2011). Critically, Portugal's mainstream political parties are primarily associations for the attainment of power. Yet, this also means that they have a strong sense of when to leave power in order to preserve themselves long term. In the specific case of the Portuguese bailout programme, this meant, for instance, that the then Socialist government asked for a bailout from the Troika of European Union, European Central Bank and the International Monetary Fund, yet then resigned to call for a snap general election. This meant that, in some ways at least, the established parties remained untarnished by what was to unfold: The Socialists could credibly claim not to be directly responsible for the consequences of the bailout and associated austerity programmes, whilst the Conservatives could credibly claim not to be responsible for the situation which led to the need for a bailout in the first place.

A third factor which explains the absence of an explicit populist movement in the country is demographic. In simple terms, those who might lead such a movementthe young-voted with their feet (and not at the ballot box) and left the country. Youth migration has surged since 2010 (Heinke 2016), leading some to claim that Portugal's younger generation has chosen 'emigration, not revolution' (Llana 2015). A potential revolutionary movement was therefore killed off, at least for the time being, by the very economic circumstances that might facilitate it. As a consequence, what protests there have been in Portugal have come largely from the older generation, hit hard by pension reforms and cuts to public services such as healthcare (ibid). These protests might be vociferous, but they do not threaten the system as a whole.

Finally, in Portugal, it has been possible to claim that the intervention by the Troika has been a success and one achieved in a relatively short time. The country exited its bailout programme in 2014 with governments claiming that the country can, once again, 'stand on its own two feet' (Amaro 2017). Recent data suggests that GDP per head in 2018 was just under 19,000 euros in 2018, compared with just over 16,000 euros in $2013 .{ }^{11}$ Whilst the country was, at the time of the bailout, in a deep economic recession, GDP has now been growing at more than $2 \%$ per year since 2016. At the same time, unemployment has fallen from more than $16 \%$ in

${ }^{11}$ Data for this section from https://www.focus-economics.com/countries/portugal. Accessed 15 May 2019. 
2013 to less than $10 \%$ in 2018. Linked to this, personal consumption has grown consistently since 2014 , reflected in retail sales growth. ${ }^{12}$ The medicine might have been bitter, so the argument goes, but it has had the desired effect, a line which the EU has certainly been pushing hard (Centeno 2018).

Yet, the above only tells part of the story. Populism may not be explicit in the way it is in Greece or Spain or Italy. However, this does not mean that there are no populist tendencies. First of all, it is worth noting that, following the inconclusive legislative election of 2015, a relatively radical-looking left-wing government did take power, replacing the centre-right government which had implemented the austerity measures described above (De Georgi and Santa-Pereira 2016). This does suggest that there was 'punishment' for these measures at the ballot box. Equally, it is worth noting that the government which took power, a minority administration led by Prime Minister Antonio Costa, has since relied on the support of the Portuguese Communist Party which, as argued above, has traditionally been the party of protest in times of crisis (ibid.). There was, therefore, protest, albeit within the context of the relatively benign conditions of Portugal.

It is also noticeable that the government has, since taking power in 2015, veered leftwards politically. Developing a strong anti-austerity narrative, some measures with a populist appeal—such as partially reversing public sector salary cuts—have sustained the government's popularity whilst changing the tone of the domestic debate of one from crisis management to optimism (Jones 2017). In other words, the government has managed to adopt some populist measures and tactics (the importance of narrative, for instance) and applied it to the country's specific circumstances whilst following a clear political line which was different from previous years and previous governments. In doing so, it attended to at least some of the demands that were made by civil society during the worst years of the crisis and the austerity which followed. It also provided a 'human touch' to its policies, focusing on such issues - the partial reversal of salary cuts, for instance - which make a clear, and almost immediate, difference to people's lives. In other words, it has adapted populism to the particular circumstances of the system within which it worked (Lorenz 2018).

The critical point, then, is that Portugal was not that different from other countries in having within its society and political system populist tendencies (see also Freire and Santana-Pereira 2019), but how the system managed to absorb and utilize these tendencies without causing it to rupture. It had adaptive capacity. This adaptive capacity, however, will be tested in the coming years as Portugal faces up to some of the structural challenges discussed above which resulted in, and sustained, the crisis in the first place and which have the potential to alter the dynamics of society and the current political system.

\footnotetext{
${ }^{12}$ Data from https://tradingeconomics.com/portugal. Accessed 15 May 2019. It is worth noting that the causal link between the policies of the troika and the more positive economic outlook has been questioned. See, for instance, Pedroso (2014); Jones (2017).
} 


\section{Future Challenges}

In spite of the good news on the economic front, there have been some suggestions from analysts that the current recovery may not be all that it seems. The first reason for this is simply the impact the depth of the recession has had in terms of confidence, both in the country as a whole and on the part of the population. Yet, trust in the sustainability of the economic recovery-and the government policies to ensure such sustainability - is absolutely vital. Portugal still has the third-highest debt ratio of the European Union, standing currently at $120 \%$ of GDP. ${ }^{13}$ In other words, the country is in no way 'out of the woods'.

More critically still, however, than this snapshot are long-term trends. Most crucial, perhaps, is the demographic development already touched upon above. The great exodus of the country's young population during the crisis years represents Portugal with a significant demographic challenge: It has one of the oldest populations in Europe, with all that this implies for the Labour market but also for the health and pension system. Therefore, it has to either try and 'repatriate' and retain its youngsters or encourage immigration. Yet, this in itself may shift the very conditions which have insulated the country from an explicit populist challenge (Khalip 2015). Furthermore, the government will have to tackle, structurally, the country's social security system to be sustainable in the long term.

Equally, the country's economic base remains fragile. A significant part of the current recovery has been based on a booming tourism sector. Yet, this sector is notoriously fickle and subject to outside influences and factors over which the government itself may have little to no control. International competitiveness of Portuguese businesses remains a significant concern, linked to age-old problems of the education system, already referred to at the start of this text, which, in simple terms, does not produce enough people with the kind of skills which would allow for a profound reform of the economic system of the country. These challenges, in turn, are linked to the structure of the Portuguese state, which is still often seen as too slow and unresponsive, both to the demands of business and the population at large (IMF 2018; OECD 2015). In other words, having overcome the immediate crisis, the government is now facing up challenges very similar to those which previous governments faced and whose inability to confront these challenges significantly contributed to the crisis in the first place.

Yet, it is unclear whether the current government has the capacity to deliver such reforms. In many ways, in fact, the current government was given sustainability and purpose by the gravity of the situation it found itself in upon assuming power. With the immediate emergency passed, the political dynamics inevitably change which may expose more of the differences between the partners in the left-wing alliance than had previously been the case. In recent months, there has been a noticeable emergence of tensions between those advocating a wholesale abandonment of aus-

${ }^{13}$ Data from https://tradingeconomics.com/portugal/government-debt-to-gdp. Accessed 15 May 2019. 
terity policies and those, around the current Prime Minister, advocating for a more moderate and incremental change of course away from the policies of the "bailout era'. It remains to be seen how these changes impact on the current left-wing coalition elected in October 2019 (Ames 2019).

In this respect, Portugal faces very similar types of challenges to the ones that it has faced ever since re-democratization: Structural reforms which would allow the country to become far more pro-active in avoiding crises rather than react once a crisis has hit. The key challenge, then, for a system which has shown itself remarkably resilient is to become one whose conditions allow for crisis avoidance. This is critical since, as has been shown, the absence of explicitly populist parties does not mean the absence of conditions which can foster and incubate populism. In fact, as has been argued, the make-up of the current government and some of the policies it pursues are signals that populist tendencies exist within society which governments are happy to respond to. History over the last 45 years suggests that the country is very capable to controlling and channelling these populist tendencies in a constructive and productive manner. Yet, with the challenges it still faces, vigilance is needed to ensure that this continues and can be used in such a way as to allow the country to address the strategic problems it clearly still has, even, or because of, years of crisis and austerity.

\section{Conclusions}

Portugal has often been held up, not least by the European Union, as a posterchild of its policies in response to the crisis of 2008 and beyond. As shown, the data clearly illustrates the improvement the Portuguese economy has undergone during the last few years after emerging from a deep recession. The fact that it has done so without throwing the political system into turmoil through the emergence of explicitly populist parties from either the Left or the Right is a testament to the system's robustness and adaptability. It is obviously, based on the historical evidence since re-democratization in 1974, a remarkably adaptive and resilient system. Yet, as I hope to have illustrated, it would be too simplistic to make a linear connection between the policies and Portugal's economic upturn. In fact, many have questioned both this link and the depth and sustainability of this upturn.

The reasons for these doubts are founded in the historical realities of the country. As illustrated, Portugal has had a history of booms and busts over the last few decades, grounded in an inability to address the structural weaknesses of the economy, ranging from education to productivity to the over-reliance on foreign capital and economic sectors more vulnerable to outside shocks. As yet, the country has shown relatively little, even in this crisis cycle, to suggest that it can overcome these cycles of boom and bust.

It is this lack of evidence in terms of profound structural reforms which means that the spectre of a populist surge cannot be discounted for definitive. So far, populist tendencies and demands have been absorbed into the mainstream of this system. 
Yet, the lack of change in the fundamentals of the Portuguese economy and society suggests that another crisis could well occur. Whether the resilience of the systems would hold again in such a scenario is open to question. Portugal, in short, needs to remain vigilant.

\section{References}

Amaro, S. (2017). How Portugal came back from the brink - And why austerity could have played a key role. https://www.cnbc.com/2017/08/02/how-portugal-came-back-from-thebrink.html. Accessed 15 May 2019.

Ames, P. (2019). Portugal splashes the cash ahead of elections', Politico, 10th January 2019. https://www.politico.eu/article/as-elections-loom-portugal-backs-major-infrastructure-investments-antonio-costa-socialists/. Accessed 15 May 2019.

Bale, T. (2008). European politics-A comparative introduction. Basingstoke: Palgrave.

Barbosa, E., Pereira, S., \& Brandão, E. (2013). The shadow economy in Portugal: An analysis using the MIMIC model. In FEP Working Papers 514, December 2013. Porto: Universidade do Porto.

Bittner, J. (2010). So nicht, Europa: Die drei grossen Fehler der EU, (Munich: DTV Premium).

Centeno, M. (2018). From sick man to poster boy: Portugal's successful recovery from the euro crisis. Speech by Eurogroup President and Portugal's minister of finance, Mário Centeno, Harvard University, 18th March 2018. https://www.consilium.europa.eu/media/33780/speechpeg-harvard-april-2018.pdf. Accessed 15 May 2019.

Costa, L., Martins, N. O., \& Guedes de Oliveira, F. (2016). Portugal's bailout and the crisis of the European Union from a capability perspective. Cambridge Journal of Economics, 40, 1479-1496.

De Georgi, E., \& Santana-Pereira, J. (2016). The 2015 Portuguese legislative election: Widening the coalitional space and bringing the extreme left in. South European Politics and Society, 21(4), 451-468.

Freire, A. \& Santana-Pereira, J. (2019). From austerity politics and democratic crisis to austerity relief and democratic renewal? The Portuguese case, 2008-2019. Paper presented at the conference 'Crisis management and democracy in EU and Latin America: Lessons learned', Athens, Greece, June 2019.

Giddens, A. (2015). Turbulent and mighty continent - What future for Europe? Cambridge: Polity.

Heinke, R. (2016). Portugal's unwanted youth. Heinrich Böll Stiftung, 14th January 2016. https:// eu.boell.org/en/2016/01/14/portugals-unwanted-youth. Accessed 15 May 2019.

IMF (2018). Portugal-recovery and risks. IMF Country Focus. https://www.imf.org/en/News/ Articles/2018/09/11/na091318-portugal-recovery-and-risks. Accessed 15 May 2019.

Jones, O. (2017). No alternative to austerity? That lie has now been nailed. The Guardian, 24th August 2017. https://www.theguardian.com/commentisfree/2017/aug/24/austerity-lie-deepcuts-economy-portugal-socialist. Accessed 15 May 2019.

Khalip, A. (2015). Portugal's brain drain spells lasting headache for election winner. https:// uk.reuters.com/article/uk-portugal-election-braindrain-idUKKCNORU1HZ20150930. Accessed 15 May 2019.

Krugman, P. (2012). End this depression now. London: W. W. Norton \& Company.

Lane, P. R. (2012). The European sovereign debt crisis. Journal of Economic Perspectives, 26(3), 49-68.

Lehmann, K. (2018). The crisis of the European Union as a complex adaptive system. Journal of Common Market Studies, 56(4), 971-988.

Llana, S. M. (2015). Austerity bites Portugal as much as Greece. Why no populist movement?, Christian Science Monitor, 10th August 2015. https://www.csmonitor.com/World/ 
Europe/2015/0810/Austerity-bites-Portugal-as-much-as-Greece.-Why-no-populistmovement. Accessed 15 May 2019.

Lloyd-Jones, S. (2001). Portugal's history since 1974. CPHRC Working Papers, 2(1).

Lobo, M. C. (2001). The role of political parties in Portuguese democratic consolidation. Party Politics, 7(5), 643-653.

Lorenz, T. (2018). As Europe moves right, Portugal veers left-and thrives. World Politics Review, 2nd January 2018. https://www.worldpoliticsreview.com/articles/23899/as-europe-movesright-portugal-veers-left-and-thrives. Accessed 15 May 2019.

Lourtie, P. (2011). Understanding Portugal in the context of the euro crisis. Paper prepared for resolving the European debt crisis, a conference hosted by the Peterson Institute for International Economics and Bruegel, Chantilly, France, September 13-14, 2011. https://piie. com/publications/papers/lourtie20110913.pdf. Accessed 15 May 2019.

Magalhães, P. (2011). Elections, parties and policy-making institutions in democratic Portugal. In A. C. Pinto (Ed.), Contemporary Portugal: Politics, society, and culture. New York: Columbia University Press.

Morlino, L., \& Raniolo, F. (2017). The impact of the economic crisis on South European democracies. Basingstoke: Palgrave.

OECD. (2015). OECD skills strategy diagnostic report: Executive summary Portugal. Paris: OECD.

Pedroso, P. (2014). Portugal and the global crisis: The impact of austerity on the economy, the social model and the performance of the state. In Study. Berlin: Friedrich Ebert Stiftung.

Pereira, P. T., \& Wemans, L. (2012). Portugal and the global financial crisis - Short-sighted politics, deteriorating public finances and the bailout imperative. In WP 26/2012/DE/UECE. Lisbon: Technical University.

Portugal, P. (2015). The Portuguese economic crisis: Policies and outcomes. In Policy brief. Gütersloh: Bertelsmann Stiftung.

Reis, R. (2013). The Portuguese slump and crash and the euro crisis. Brookings papers on economic activity, NBER Working Paper No. 19288. Washington, DC: Brookings Institution. https://www.brookings.edu/bpea-articles/the-portuguese-slump-and-crash-and-the-euro-crisis/. Accessed 15 May 2019.

Open Access This chapter is licensed under the terms of the Creative Commons Attribution 4.0 International License (http://creativecommons.org/licenses/by/4.0/), which permits use, sharing, adaptation, distribution and reproduction in any medium or format, as long as you give appropriate credit to the original author(s) and the source, provide a link to the Creative Commons license and indicate if changes were made.

The images or other third party material in this chapter are included in the chapter's Creative Commons license, unless indicated otherwise in a credit line to the material. If material is not included in the chapter's Creative Commons license and your intended use is not permitted by statutory regulation or exceeds the permitted use, you will need to obtain permission directly from the copyright holder.

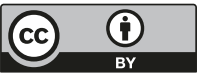

